\title{
EFEKTIVITAS PENERBITAN IZIN MENDIRIKAN BANGUNAN (IMB) OLEH CAMAT MALINAU BARAT BERDASARKAN PERATURAN BUPATI MALINAU NOMOR 14 TAHUN 2011
}

\author{
Meli Juita \\ Yayasan Pendidikan Intimung Politeknik Malinau \\ Jl. Ladang, Desa Malinau Seberang Kecamatan Malinau Utara \\ Email: melijuitash@yahoo.co.id
}

\begin{abstract}
Ineffective issuance of building permit with respect to the lack of public awareness in the care of the building permit and West Malinau District Government officials also do not understand fully about the implementation of the issuance of building permit by sub-district after the enactment of the decree Malinau Number 14 In 2011. Problem formulation that is what degree of effectiveness publishing Building Permit conducted by the sub-district of West Malinau Malinau after the enactment of the decree Number 14 of 2011? And what factors or elements of the most dominant influence on the level of effectiveness of the issuance of building permit conducted by the sub-district of West Malinau Malinau after the enactment of the decree Number 14 of 2011?. The purpose of this paper is to determine the level of effectiveness of the publication Building Permit and the factors or elements of the most dominant influence on the level of effectiveness of the issuance of building permit conducted by the sub-district of West Malinau Malinau after the enactment of the decree Number 14 of 2011. Methods used is the juridical-empirical. The results of the study that the effectiveness of the publication Building Permit by sub-district of West Malinau Malinau Regent Regulation Number 14 of 2011 is not effective because of the factor structure, substance, and culture. The dominant factors or elements that most influence on the level of effectiveness of the publication Building Permit by Malinau District Head West after the enactment of the decree Number 14 of 2011 Malinau that legal factors, law enforcement factor, factor means or facilities, community factors, and cultural factors
\end{abstract}

Key words: affectivity, regulatory regent, building permit

\begin{abstract}
Abstrak
Ketidakefektifnya penerbitan Izin Mendirikan Bangunan (IMB) berkenaan dengan kurangnya kesadaran masyarakat dalam mengurus Izin Mendirikan Bangunan (IMB) dan aparatur Pemerintah Kecamatan Malinau Barat juga belum memahami dengan sepenuhnya mengenai pelaksanaan penerbitan Izin Mendirikan Bangunan (IMB) oleh Camat setelah diberlakukannya Peraturan Bupati Malinau Nomor 14 Tahun 2011. Rumusan Masalah yaitu Bagaimana tingkat efektivitas penerbitan Izin Mendirikan Bangunan (IMB) yang dilakukan oleh Camat Malinau Barat setelah diberlakukannya Peraturan Bupati Malinau Nomor 14 Tahun 2011? Dan Apa faktor atau unsur dominan yang paling berpengaruh terhadap tingkat efektivitas penerbitan Izin Mendirikan Bangunan (IMB) yang dilakukan oleh Camat Malinau Barat setelah diberlakukannya Peraturan Bupati Malinau Nomor 14 Tahun 2011?. Tujuan penulisan ini yaitu untuk mengetahui tingkat efektivitas penerbitan Izin Mendirikan Bangunan (IMB) dan faktor atau unsur dominan yang paling berpengaruh terhadap tingkat efektivitas penerbitan Izin Mendirikan Bangunan (IMB) yang dilakukan oleh Camat Malinau Barat setelah diberlakukannya Peraturan Bupati
\end{abstract}


Malinau Nomor 14 Tahun 2011. Metode yang digunakan adalah yuridis-empiris. Hasil dari penelitian bahwa efektivitas penerbitan Izin Mendirikan Bangunan (IMB) oleh Camat Malinau Barat berdasarkan Peraturan Bupati Malinau Nomor 14 Tahun 2011 belum berjalan secara efektif karena dari faktor struktur, substansi, dan kultur. Faktor atau unsur dominan yang paling berpengaruh terhadap tingkat efektivitas penerbitan Izin Mendirikan Bangunan (IMB) oleh Camat Malinau Barat setelah diberlakukannya Peraturan Bupati Malinau Nomor 14 Tahun 2011 yaitu faktor hukum, faktor penegak hukum, faktor sarana atau fasilitas, faktor masyarakat, dan faktor kebudayaan

Kata kunci: efektivitas, peraturan bupati, izin mendirikan bangunan

\section{Latar Belakang}

Negara Republik Indonesia yang merdeka merupakan Negara yang berdaulat, yang terdiri atas pemerintah pusat dan daerah. Pemerintah pusat dengan dibantu pemerintah daerah melaksanakan berbagai kegiatan memberikan keleluasan kepada daerah untuk menyelenggarakan otonomidaerah.Pemberian kewenangan dalam penyelenggaraan otonomi daerah adalah untuk mendorong upaya peningkatan kesejahteraan rakyat, pemerataan dan keadilan, demokratisasi dan penghormatan terhadap budaya lokal serta memperhatikan potensi dan keanekaragaman daerah. Kewenangan merupakan hak dan atau kewajiban untuk menjalankan satu atau beberapa fungsi manajemen (pengaturan, perencanaan, pengorganisasian, pengurusan dan pengawasan) atas suatu objek tertentu yang ditangani oleh pemerintahan. ${ }^{1}$ Guna pendewasaan daerah menuju swasembada disegala bidang, kepada pemerintah daerah diberikan otonomi nyata yang seluas-luasnya dalam batas-batas ikatan Negara kesatuan, sehingga asas hubungan kerja Pemerintah Pusat dan Pemerintah Daerah adalah asasasas desentralisasi dan dekonsentrasi serta tugas pembantuan. ${ }^{2}$

Berbagai macam jenis urusan yang ada di Kabupaten Malinau berkaitan dengan pelayanan umum (public services), salah satunya adalah urusan pemerintah Kabupaten Malinaudarisegiperizinan.Untukmemberikan pelayanan yang maksimal kepada masyarakat Kabupaten Malinau didalam mengurus izin, pemerintah Kabupaten Malinau memberikan kemudahan bagi masyarakat yang ingin mengurus Izin Mendirikan Bangunan (IMB) melalui Kantor Kecamatan yang berada dalam wilayah Kabupaten Malinau berdasarkan Peraturan Bupati Malinau Nomor 14 Tahun 2011 Tentang Pendelegasian Sebagian Wewenang Bupati Kepada Camat. Namun, dalam pelaksanaannya efektivitas penerbitan Izin Mendirikan Bangunan (IMB) oleh Camat Malinau Barat setelah diberlakukannya Peraturan Bupati tersebut tidak sesuai dengan harapan pemerintah daerah Kabupaten

1 Agussalim Andi Gadjong, Pemerintahan Daerah Kajian Politik dan Hukum, Ghalia Indonesia, Bogor, 2007, hlm. 93.

2 Diana Halim Koentjoro, Hukum Administrasi Negara, Ghalia Indah, Bogor Selatan, 2004, hlm. 31. 
Malinau. Efektivitas adalah suatu usaha yang dilakukan secara sadar dan rasional untuk menciptakan ketepatan penggunaan berbagai sumber yang dimiliki oleh suatu organisasi sehingga memberikan manfaat untuk meningkatkan kesejahteraan sesuai dengan tuntutan kehidupan. ${ }^{3}$

Ketidakefektifnya penerbitan Izin Mendirikan Bangunan (IMB) oleh Camat Malinau Barat berkenaan dengan masih kurangnya kesadaran masyarakat didalam mengurus Izin Mendirikan Bangunan (IMB) baik yang telah memiliki bangunan (rumah) maupun yang sedang dalam proses pembangunan serta masih banyaknya masyarakat yang belum mengetahui Peraturan Bupati Nomor 14 Tahun 2011, meskipun pemerintah daerah dalam hal ini Kantor Pelayanan Terpadu Kabupaten Malinau bersama Pemerintah Kecamatan Malinau Barat telah melakukan sosialisasi kepada masyarakat mengenai Peraturan Bupati Malinau Nomor 14 Tahun 2011. Kemudian masyarakat yang meskipun telah mengetahui bahwa Camat Malinau Barat telah memiliki kewenangan untuk dapat menerbitkan Izin Mendirikan Bangunan (IMB) skala kecil berdasarkan Peraturan Bupati Nomor 14 Tahun 2011 tersebut tetap saja tidak mengindahkan atau mengurus Izin Mendirikan Bangunan (IMB) di Kecamatan Malinau Barat karena terkendala pada biaya administrasi yang dikenakan apabila mengurus Izin Mendirikan Bangunan (IMB).
Aparatur kecamatan juga masih belum memahami sepenuhnya mengenai pelaksanaan penerbitan Izin Mendirikan Bangunan (IMB) yang dilakukan oleh Camat Malinau Barat setelah diberlakukannya Peraturan Bupati Malinau Nomor 14 Tahun 2011, karena Pemerintah Kecamatan Malinau Barat pernah menerbitkan Izin Mendirikan Bangunan (IMB) dengan ketetapan biaya yang tidak sesuai dengan perhitungan yang telah diatur dalam Peraturan Bupati, dimana penetapan dan perhitungan biaya yang dikenakan pada setiap kepengurusan izin ditetapkan dalam Peraturan Daerah Kabupaten Malinau Nomor 5 Tahun 2001 Tentang Izin Mendirikan Bangunan. Hal ini juga berkenaan dengan kurangnya koordinasi antara aparatur pemerintah yang menangani perizinan yaitu dari pihak Pemerintah Kecamatan Malinau Barat dan Kantor Pelayanan Terpadu Kabupaten Malinau yang menimbulkan perbedaan dalam melaksanakan penerbitan Izin Mendirikan Bangunan (IMB) berdasarkan Peraturan Bupati Malinau Nomor 14 Tahun 2011, sehingga efektivitas dari penerbitan Izin Mendirikan Bangunan (IMB) yang dilakukan oleh Camat Malinau Barat tersebut tidak berjalan sebagaimana mestinya. Dengan demikian, maka sangat diperlukan tindakan pemerintah Kabupaten Malinau terkait dengan pelaksanaan daripada penerbitan Izin Mendirikan Bangunan (IMB) yang dilakukan oleh Camat Malinau Barat setelah diberlakukannya Peraturan Bupati

3 Makmur, Efektivitas Kebijakan Kelembagaan Pengawasan, Refika Aditama, Bandung, 2011, hlm. 141. 
Nomor 14 Tahun 2011 agar dapat terlaksana secara efektif.

\section{Pembahasan}

\section{A. Tingkat Efektivitas Penerbitan Izin} Mendirikan Bangunan (IMB) yang Dilakukan oleh Camat Malinau Barat setelah Diberlakukannya Peraturan Bupati Malinau Nomor 14 Tahun 2011

Keefetivitasan penerbitan Izin Mendirikan Bangunan (IMB) yang dilakukan oleh Camat setelah diberlakukannya Peraturan Bupati Malinau Nomor 14 Tahun 2011 sejatinya terletak pada faktor-faktor yang mempengaruhinya sehingga dapat berjalan secara efektif. Faktor-faktor tersebut adalah (a) struktur, yaitu Pemerintah Daerah Kabupaten Malinau dari Desa, Kecamatan Malinau Barat dan Kantor Pelayanan Terpadu (KPT) Kabupaten Malinau; (b) substansi, yaitu Peraturan Bupati Malinau Nomor 14 Tahun 2011 Tentang Pendelegasian Sebagian Wewenang Bupati Kepada Camat; (c) kultur hukum, yaitu sikap masyarakat terhadap hukum dalam hal ini adalah pelaksanaan penerbitan Izin Mendirikan Bangunan (IMB) oleh Camat Malinau Barat setelah diberlakukannya Peraturan Bupati Malinau Nomor 14 Tahun 2011 Tentang Pendelegasian Sebagian Wewenang Bupati Kepada Camat. Kesadaran masyarakat akan menjadi faktor pendukung, akan tetapi apabila masyarakat tidak mematuhi aturan yang ada, maka masyarakat akan menjadi faktor penghambat utama dalam penegakan peraturan hukum. ${ }^{4}$

\section{Faktor struktur}

Menurut Lawrence M. Friedman, struktur yaitu keseluruhan institusi-institusi hukum yang ada beserta aparatnya, mencakupi antara lain kepolisian dengan para polisinya, kejaksaan dengan jaksanya, pengadilan dengan para hakimnya, dan lain-lain. ${ }^{5}$ Dalam pelaksanaan penerbitan Izin Mendirikan Bangunan (IMB) oleh Camat Malinau Barat setelah diberlakukannya Peraturan Bupati Malinau Nomor 14 Tahun 2011 Tentang Pendelegasian Sebagian Wewenang Bupati Kepada Camat, strukturnya dimulai dari Desa, Kecamatan Malinau Barat dan Kantor Pelayanan Terpadu (KPT) Kabuaten Malinau. Kepengurusan Izin Mendirikan Bangunan (IMB), dimulai dari Kepala Desa yang mengeluarkan surat rekomendasi untuk Izin Mendirikan Bangunan (IMB) bagi pemohon. Surat rekomendasi tersebut sebagai dasar pemohon untuk mengurus perizinan di Kecamatan Malinau Barat.

Kantor Pelayanan Terpadu (KPT) Kabupaten Malinau melakukan sosialisasi mengenai Peraturan Bupati Malinau Nomor 14 Tahun 2011 Tentang Pendelegasian Sebagian Wewenang Bupati Kepada Camat kepada aparatur pemerintahan baik tingkat

4 Achmad Ali, Menguak Teori Hukum (Legal Theory) dan Teori Peradilan (Judicialprudence) Termasuk Interpretasi Undang-undang (Legisprudence), Prenada Media Group, 2009, hlm. 204.

5 Ibid. 
kecamatan, desa maupun masyarakat di Kecamatan-Kecamatan yang ada dalam wilayah Kabupaten Malinau termasuk Kecamatan Malinau Barat, selain itu Kantor Pelayanan Terpadu (KPT) Kabupaten Malinau melakukan sosialisasi melalui media massa seperti melalui radio maupun koran. Tujuan sosialisasi tersebut agar masyarakat mengetahui mengenai Peraturan Bupati itu dan dapat mengurus Izin Mendirikan Bangunan (IMB) di Kecamatan. ${ }^{6}$

Kepala Desa Long Bila yaitu Rining Biang, mengatakan bahwa untuk mengefektifkan penerbitan Izin Mendirikan Bangunan (IMB) oleh Camat Malinau Barat setelah diberlakukannya Peraturan Bupati Malinau Nomor 14 Tahun 2011, pihak Pemerintah Desa Long Bila berinisiatif dengan berdasarkan kesepakatan bersama oleh aparat desa bahwa untuk meningkatkan minat masyarakat Desa Long Bila, pemerintah desa memberikan kemudahan dengan membantu membayar sebagian biaya retribusi Izin Mendirikan Bangunan (IMB) dengan catatan bahwa Izin Mendirikan Bangunan (IMB) tersebut adalah Izin Mendirikan Bangunan (IMB) skala kecil. ${ }^{7}$ Meskipun telah ada inisiatif dari Pemerintah Desa Long Bila, hal ini juga tidak dapat menyebabkan dapat terefektifnya pelaksanaan Peraturan Bupati Malinau Nomor 14 Tahun 2011 tersebut.

Aparatur Pemerintah Kecamatan Malinau Barat juga belum bisa memahami dengan benar mengenai isi dari Peraturan Bupati Malinau Nomor 14 Tahun 2011 Tentang Pendelegasian Sebagian Wewenang Bupati Kepada Camat, hal ini dikarenakan Pemerintah Kecamatan Malinau Barat pernah menerbitkan Izin Mendirikan Bangunan (IMB) dengan skala besar dan dengan biaya retribusi yang tidak sesuai dengan Peraturan Bupati Nomor 14 Tahun 2011, seperti yang tercantum dalam Peraturan Bupati Malinau Nomor 14 Tahun 2011 Tentang Pendelegasian Sebagian Wewenang Bupati Kepada Camat Pasal 3 Huruf (S) Izin Mendirikan Bangunan (IMB) skala kecil telah jelas bahwasanya Pemerintah Kecamatan hanya bisa menerbitkan Izin Mendirikan Bangunan (IMB) skala kecil serta pada persyaratan dan biaya retribusi permohonan Izin Mendirikan Bangunan (IMB) skala kecil sesuai dengan Peraturan Daerah Kabupaten Malinau Nomor 5 Tahun 2001 pada Bab V tentang retribusi izin bangunan. Sehingga penerbitan Izin Mendirikan Bangunan (IMB) yang dilakukan oleh Camat Malinau Barat tidak sesuai dengan Peraturan Bupati Nomor 14 Tahun 2011 dan hal tersebut menyebabkan kurang efektifnya pelaksanaan Peraturan Bupati Nomor 14 Tahun 2011. Sehubungan dengan hal tersebut, maka sebaiknya Kantor Pelayanan Terpadu (KPT) Kabupaten Malinau tidak hanya sebatas sosialisasi tetapi juga melakukan koordinasi dan intensitas komunikasi dengan Pemerintah Kecamatan Malinau Barat serta melakukan

6 Wawancara dengan Meky Gagalang, Kepala Seksi Perizinan Kantor Pelayanan Terpadu Kabupaten Malinau, 14 Agustus 2014.

7 Wawancara dengan Rining Biang, Kepala Desa Long Bila, 13 Agustus 2014. 
pemantauan secara berkala pada Kecamatan Malinau Barat mengenai pelaksaanaan penerbitan Izin Mendirikan Bangunan (IMB) oleh Camat Malinau Barat berdasarkan Peraturan Bupati Nomor 14 Tahun 2011.

\section{Substansi}

Pemerintah dalam menjalankan fungsi pengaturan dan fungsi pelayanan kepada masyarakat didalam pembuatan dan penerbitan perizinan harus berdasarkan pada peraturan perundang-undangan atau harus berdasarkan asas legalitas. Agar pelayanan kepada masyarakat keterkaitannya dengan pelayanan, pengurusan serta penerbitan perizinan khususnya Izin Mendirikan Bangunan (IMB) lebih maksimal, Pemerintah Daerah Kabupaten Malinau mempunyai Peraturan Daerah Kabupaten Malinau Nomor 5 Tahun 2001 Tentang Izin Mendirikan Bangunan. Seiring dengan semakin pesatnya perkembangan kependudukan dalam hal pembangunan, maka Pemerintah Daerah Kabupaten Malinau menerbitkan Peraturan Bupati Malinau Nomor 14 Tahun 2011 Tentang Pendelegasian Sebagian Wewenang Bupati Kepada Camat. Sehingga substansi hukum dalam kajian ini adalah Peraturan Bupati Malinau Nomor 14 Tahun 2011 Tentang Pendelegasian Sebagian Wewenang Bupati Kepada Camat. Substansi hukum adalah aturan, norma, dan pola perilaku nyata manusia yang berada dalam sistem.
Substansi juga berarti produk yang dihasilkan oleh orang yang berbeda di dalam sistem hukum itu, mencakup keputusan yang mereka keluarkan, aturan baru yang mereka susun. Substansi juga mencakup hukum yang hidup (living law), dan bukan hanya aturan yang ada dalam Kitab Undang-Undang atau law books. ${ }^{8}$

Menurut Syahrinnudin, bahwa Peraturan Bupati Malinau Nomor 14 Tahun 2011, belum jelas dengan alasan bahwasanya didalam Peraturan Bupati tersebut tidak dicantumkan mengenai ukuran yang tepat dan terperinci mengenai pengukuran Izin Mendirikan Bangunan (IMB) dalam skala kecil. Sehingga hal tersebut menimbulkan kebingungan bagi Pemerintah Kecamatan Malinau Barat. ${ }^{9}$ Dengan demikian penerbitan Izin Mendirikan Bangunan (IMB) yang dilakukan oleh Camat Malinau Barat setelah diberlakukannya Peraturan Bupati Malinau Nomor 14 Tahun 2011 secara substansi belum bisa berjalan secara efektif, karena masih ada yang belum jelas dalam Peraturan Bupati tersebut. Secara substansi Peraturan Bupati Malinau Nomor 14 Tahun 2011 agar dapat berjalan secara efektif, maka Peraturan Bupati ini harus diubah oleh Pemerintah Daerah Kabupaten Malinau dengan isi yang lebih jelas dan konkrit sehingga tidak menimbulkan kesalahan dalam pelaksanaannya serta tidak menimbulkan kebingungan bagi Pemerintah Kecamatan

8 Achmad Ali, Loc.cit., hlm. 204.

9 Wawancara dengan Syahrinnudin, Kepala Seksi Ketertiban Umum Kecamatan Malinau Barat, 14 Agustus 2014. 
yang menjalankan Peraturan Bupati Nomor 14 Tahun 2011 Tentang pendelegasian Sebagian Wewenang Bupati Kepada Camat.

\section{Kultur hukum}

Kultur hukum yaitu opini-opini, kepercayaan-kepercayaan (keyakinankeyakinan) kebiasaan-kebiasaan, cara berfikir, dan cara bertindak, baik dari para penegak hukum maupiun dari warga masyarakat, tentang hukum dan berbagai fenomena yang berkaitan dengan hukum. ${ }^{10}$ Kultur hukum dalam kajian ini adalah suatu sikap dan kesadaran masyarakat Kabupaten Malinau khususnya masyarakat di Kecamatan Malinau Barat terhadap penerbitan Izin Mendirikan Bangunan yang dilakukan oleh Camat Malinau Barat setelah diberlakukannya Peraturan Bupati Nomor 14 Tahun 2011.

Pemerintah Kabupaten Malinau dalam hal ini adalah Kantor Pelayanan Terpadu (KPT) dan Pemerintah Kecamatan Malinau Barat melakukan sosialisasi mengenai kewenangan Camat untuk menerbitkan Izin Mendirikan Bangunan (IMB) skala kecil berdasarkan Peraturan Bupati Malinau Nomor 14 Tahun 2011 kepada masyarakat Kecamatan Malinau Barat. Namun, setelah melakukan sosialisasi masih saja ada masyarakat yang tidak mengetahui mengenai Peraturan Bupati Nomor 14 Tahun 2011 tersebut dan tidak mengurus Izin Mendirikan Bangunan (IMB). Seperti yang terjadi pada ke empat (4) Desa yang berada dalam wilayah Kecamatan
Malinau Barat yaitu Desa Tanjung Lapang, Desa Taras, Desa Sentaban dan Desa Long Bila.

Masyrakat yang berada Desa Tanjung Lapang, Desa Taras, Desa Sentaban dan Desa Long Bila lebih banyak tidak mengetahui tentang penerbitan Izin Mendirikan Bangunan (IMB) skala kecil yang dapat dilaksanakan kepengurusan dan penerbitannya di Kecamatan Malinau Barat, sehingga ini mempengaruhi efektivitas penerbitan Izin Mendirikan Bangunan (IMB) oleh Camat Malinau Barat setelah diberlakukannya Peraturan Bupati Malinau Nomor 14 Tahun 2011, dan hal ini menunjukkan bahwa masih banyak masyarakat yang tidak memiliki Izin Mendirikan Bangunan (IMB), dan ini membuktikan bahwa sosialisasi dari Pemerintah Daerah Kabupaten Malinau ini masih kurang.

Adapun yang memiliki Izin Mendirikan Bangunan (IMB) adalah masyarakat yang mempunyai kegiatan usaha, dimana didalam mengurus Surat Izin Tempat Usaha (SITU) salah satu persyaratannya yaitu harus memiliki Izin Mendirikan Bangunan (IMB). Masyarakat yang sudah mengetahui penerbitan Izin Mendirikan Bangunan (IMB) oleh Camat Malinau Barat setelah diberlakukannya Peraturan Bupati Malinau Nomor 14 Tahun 2011 Tentang Pendelegasian Sebagian Wewenang Bupati Kepada Camat, namun tidak mengindahkan atau mentaati 
peraturan tersebut, hal ini disebabkan beberapa hal yaitu (a) tidak mengerti proses pembuatan Izin Mendirikan Bangunan (IMB); (b) takut dikenakan biaya retribusi yang mahal; (c) bahwa Izin Mendirikan Bangunan (IMB) dianggap tidak penting. Hal ini mengakibatkan kurang efektifnya penerbitan Izin Mendirikan Bangunan (IMB) yang dilakukan oleh Camat Malinau Barat sesuai dengan Peraturan Bupati Malinau Nomor 14 Tahun 2011 Tentang Pendelegasian Sebagian Wewenang Bupati Kepada Camat di Kecamatan Malinau Barat. Untuk itu maka Pemerintah Daerah Kabupaten Malinau dalam hal ini Kantor Pelayanan Terpadu dan Pemerintah Kecamatan Malinau Barat harus melibatkan Pemerintah Desa. Dimana pemerintah Desa adalah yang paling dekat hubungan dengan masyarakat. Keterlibatan tersebut tidak hanya melalui sosialisasi saja dan rekomendasi dari Desa ke Kecamatan berkaitan dengan kepengurusan perizinan tetapi juga melakukan pendekatan personal atau pendataan masyarakat secara langsung untuk membuat Izin Mendirikan Bangunan (IMB). Sehingga penerbitan Izin Mendirikan Bangunan (IMB) yang dilakukan oleh Camat Malinau Barat berdasarkan Peraturan Bupati Malinau Nomor 14 Tahun 2011 Tentang Pendelegasian Sebagian Wewenang Bupati Kepada Camat bisa dapat berjalan secara efektif.
B. Faktor atau Unsur Dominan yang Paling Berpengaruh terhadap Tingkat Efektivitas Penerbitan Izin Mendirikan Bangunan (IMB) yang Dilakukan oleh Camat Malinau Barat setelah Diberlakukannya Peraturan Bupati Malinau Nomor 14 Tahun 2011

Penegakan Peraturan Bupati Malinau Nomor 14 Tahun 2011 Tentang Pendelegasian Sebagian Wewenang Bupati Kepada Camat, sejatinya terletak pada faktor-faktor yang paling dominan yang mempengaruhi tingkat efektivitas penerbitan Izin Mendirikan Bangunan (IMB) yang dilakukan oleh Camat Malinau Barat setelah diberlakukannya Peraturan Bupati Malinau Nomor 14 Tahun 2011. Faktor-faktor tersebut adalah sebagai berikut:

1. Faktor hukumnya sendiri

2. Faktor penegak hukum

3. Faktor sarana atau fasilitas

4. Faktor masyarakat

5. Faktor kebudayaan ${ }^{11}$

Kelima faktor tersebut saling berkaitan erat, karena merupakan tolok ukur daripada efektivitas penegakan penerbitan Izin Mendirikan Bangunan (IMB) oleh Camat Malinau Barat setelah diberlakukannya Peraturan Bupati Malinau Nomor 14 Tahun 2011 Tentang Pendelegasian Sebagian Wewenang Bupati Kepada Camat.

11 Soerjono Soekanto, Faktor-faktor yang Mempengaruhi Penegakan Hukum, RajaGrafindo Persada, Jakarta, 2010, hlm. 8. 


\section{Faktor hukum}

Salah satu prinsip dalam negara hukum adalah wetmatigheid van bestuur atau pemerintahan berdasarkan peraturan perundang-undangan. Dengan kata lain, setiap tindakan hukum pemerintah baik dalam menjalankan fungsi pengaturan maupun fungsi pelayanan harus didasarkan pada wewenang yang diberikan oleh peraturan perundang-undangan yang berlaku. ${ }^{12}$

Melalui Peraturan Daerah Kabupaten Malinau Nomor 5 Tahun 2001 Tentang Izin Mendirikan Bangunan, Pemerintah Kabupaten Malinau mempunyai kewenangan untuk menjalankan fungsi pelayanan perizinan kepada masyarakat, karena pembuatan dan penerbitan keputusan izin merupakan tindakan hukum pemerintah. Seiring dengan semakin pesatnya perkembangan pembangunan di Kabupaten Malinau dan untuk meningkatkan pelayanan yang maksimal kepada masyarakat menuju kepada pemerintahan yang baik (good government) serta dengan mempertimbangkan agar masyarakat Kabupaten Malinau yang jauh dari Kota Kabupaten Malinau mudah untuk mengurus perizinan, Pemerintah Kabupaten Malinau akhirnya menerbitkan Peraturan Bupati Malinau Nomor 14 Tahun 2011 Tentang Pendelegasian Sebagian Wewenang Bupati Kepada Camat, Peraturan Bupati Malinau Nomor 14 Tahun 2011 ini juga berlaku bagi Kecamatan Malinau Barat.

Pelaksanaan penerbitan Izin Mendirikan Bangunan (IMB) skala kecil yang diperoleh
Camat Malinau Barat berdasarkan Peraturan Bupati Malinau Nomor 14 Tahun 2011 juga terdapat ketidakjelasan mengenai ukuran skala kecil yang dimaksud dalam Peraturan Bupati Nomor 14 Tahun 2011 tersebut, karena didalam Peraturan Bupati Nomor 14 Tahun 2011 tidak ada menjelaskan ukuran yang detail atau ukuran yang konkrit mengenai Izin Mendirikan Bangunan (IMB) skala kecil. Sehingga hal ini menjadi faktor yang menghambat keefektivitasan penerbitan Izin Mendirikan Bangunan (IMB) yang dilakukan oleh Camat setelah diberlakukannya Peraturan Bupati Malinau Nomor 14 Tahun 2011. Dengan demikian maka, Pemerintah Daerah Kabupaten Malinau perlu mengubah Peraturan Bupati Malinau Nomor 14 Tahun 2011 dengan menjelaskan secara detail dan terperinci mengenai ukuran skala kecil yang menjadi kewenangan Camat dalam menerbitkan Izin Mendirikan Bangunan (IMB), sehingga tidak menimbulkan hambatan bagi pemerintah Kecamatan yang berada dalam wilayah Kabupaten Malinau termasuk pemerintah Kecamatan Malinau Barat dalam menerbitkan Izin Mendirikan Bangunan (IMB).

\section{Faktor penegak hukum}

Penegakan hukum adalah suatu proses untuk mewujudkan keinginan-keinginan hukum menjadi kenyataan. Yang disebut keinginan-keinginan hukum dalam hal ini adalah pikiran-pikiran badan pembuat undang-undang yang dirumuskan dalam 
peraturan perundang-undangan hukum itu. Dapat dikatakan bahwa penegakan hukum merupakan serangkaian aktivitas, upaya, atau tindakan dengan mengorganisasi berbagai instrumen untuk menwujudkan apa yang dicita-citakan oleh pembentuk hukum. ${ }^{13}$

Penegak hukum juga harus dapat berkomunikasi dan mendapatkan pengertian dari masyarakat, disamping mampu membawakan atau menjalankan peranan yang dapat diterima. ${ }^{14}$ Untuk melaksanakan penerbitan Izin Mendirikan Bangunan (IMB) yang dilakukan oleh Camat Malinau Barat berdasarkan Peraturan Bupati Malinau Nomor 14 Tahun 2011, Pemerintah Kantor Pelayanan Terpadu (KPT) Kabupaten Malinau dan Pemerintah Kecamatan Malinau Barat hanya melakukan sosialisasi dan memberikan pemahaman kepada masyarakat di Kecamatan Malinau Barat termasuk Desa Tanjung Lapang, Desa Taras, Desa Sentaban dan Desa Long Bila mengenai pentingnya mengurus perizinan termasuk Izin Mendirikan Bangunan (IMB) dan antara pihak Pemerintah Kecamatan Malinau Barat dan Kantor Pelayanan Terpadu (KPT) Kabupaten Malinau hanya melakukan koordinasi saja, sementara akuntabilitas dari setiap program kerja termasuk mengenai perizinan yang telah dilaksanakan oleh Pemerintah Kecamatan Malinau Barat membuat laporan kepada Bupati Malinau apabila ada Rapat Koordinasi Pengendalian Pembangunan atau Musyawarah Perencanaan Pembangunan yang biasanya dilaksanakan masing-masing 1 (satu) tahun sekali yang dihadiri oleh Bupati dan seluruh Satuan Perangkat Kerja Daerah (SKPD) Kabupaten Malinau. ${ }^{15}$

Sosialisasi-sosialisasi yang telah dilakukan oleh Kantor Pelayanan Terpadu (KPT) Kabupaten Malinau dan Pemerintah Kecamatan Malinau Barat kepada masyarakat ternyata masih belum cukup untuk mengefektifkan penerbitan Izin Mendirikan Bangunan (IMB) yang dilakukan oleh Camat Malinau Barat setelah diberlakukannya Peraturan Bupati Malinau Nomor 14 Tahun 2011. Untuk mengefektifkannya, Kantor Pelayanan Terpadu (KPT) Kabupaten Malinau sebaiknya melakukan pengawasan kepada Pemerintah Kecamatan Malinau Barat dan melibatkan Dinas Tata Kota Kabupaten Malinau dalam melakukan pengawasan terhadap penerbitan Izin Mendirikan Bangunan (IMB) yang dilakukan oleh Camat Malinau Barat, karena Dinas Tata Kota Kabupaten Malinau merupakan salah satu Satuan Kerja Perangkat Daerah (SKPD) Kabupaten Malinau yang terkait dengan pengurusan Izin Mendirikan Bangunan (IMB).

Pada pelaksanaan penerbitan Izin Mendirikan Bangunan (IMB) oleh Camat

13 Y. Sri Pudyatmoko, Perizinan Problem dan Upaya Pembenahan, Gramedia Widiasarana Indonesia, 2009, hlm. 111.

14 Soerjono Soekanto, Op.cit., hlm. 34.

15 Wawancara dengan Syahrinnudin, Kepala Seksi Ketertiban Umum Kecamatan Malinau Barat, 14 Agustus 2014. 
Malinau Barat setelah diberlakukannya Peraturan Bupati Malinau Nomor 14 Tahun 2011 faktor penegak hukum merupakan salah satu faktor yang menghambat keefektivitasan pelaksanaan penerbitan Izin Mendirikan Bangunan (IMB), sebab Dinas Tata Kota tidak pernah dilibatkan dalam melakukan pengawasan dan penertiban terhadap pembangunan yang belum memiliki Izin Mendirikan Bangunan (IMB), karena Kantor Pelayanan Terpadu (KPT) Kabupaten Malinau dan Pemerintah Kecamatan Malinau Barat belum pernah melakukan penegakan hukum terkait dengan penerbitan Izin Mendirikan Bangunan (IMB) terhadap masyarakat Kecamatan Malinau Barat khususnya masyarakat di Desa Tanjung Lapang, Desa Taras, Desa Sentaban dan Desa Long Bila. ${ }^{16}$

Pengawasan adalah suatu bentuk pola pikir dan pola tindakan untuk memberikan pemahaman dan kesadaran kepada seseorang atau beberapa orang yang diberikan tugas untuk dilaksanakan dengan menggunakan berbagai sumber daya yang tersedia secara baik dan benar, sehingga tidak terjadi kesalahan dan penyimpangan yang sesungguhnya dapat menciptakan kerugian oleh lembaga atau organisasi yang bersangkutan. ${ }^{17}$ Jadi dalam melaksanakan dan menegakkan penerbitan Izin Mendirikan Bangunan (IMB) yang dilakukan oleh Camat Malinau Barat setelah diberlakukannya Peraturan Bupati Malinau
Nomor 14 Tahun 2011, Pemerintah Kecamatan Malinau Barat tidak hanya membuat laporan dan menyampaikan hasil kegiatannya kepada Bupati melalui Rapat Koordinasi Pengendalian Pembangunan atau Musyawarah Perencanaan Pembangunan yang biasanya pelaksanaannya diadakan setahun sekali, tetapi ada pengawasan terhadap pelaksanaan penerbitan Izin Mendirikan Bangunan (IMB) oleh Camat Malinau Barat setelah diberlakukannya Peraturan Bupati Malinau Nomor 14 Tahun 2011 oleh Pemerintah Kecamatan Malinau Barat.

Penegakan hukum terhadap penerbitan Izin Mendirikan Bangunan (IMB) oleh Camat Malinau Barat setelah diberlakukannya Peraturan Bupati Malinau Nomor 14 Tahun 2011 juga seharusnya melibatkan Satuan Polisi Pamong Praja Kabupaten Malinau didalam melakukan penegakan hukum terhadap penerbitan Izin Mendirikan Bangunan (IMB) yang dilakukan oleh Camat Malinau Barat setelah diberlakukannya penerbitan Izin Mendirikan Bangunan (IMB) oleh Camat Malinau Barat berdasarkan Peraturan Bupati Malinau Nomor 14 Tahun 2011 sebagai penegak hukum dari pada Peraturan Bupati Malinau Nomor 14 Tahun 2011 tersebut. Sehingga dengan keterlibatan intansi Pemerintah ini, maka pelaksanaan daripada penerbitan Izin Mendirikan Bangunan (IMB) oleh Camat Malinau Barat tersebut dapat

\footnotetext{
16 Wawancara dengan Meky Gagalang, Kepala Seksi Perizinan Kantor Pelayanan Terpadu Kabupaten Malinau, 14 Agustus 2014.

17 Makmur, Loc.cit., hlm. 141.
} 
berjalan secara efektif dan masyarakat dapat mentaati Peraturan Bupati Nomor 14 Tahun 2011 itu. Kemudian Pemerintah Daerah Kabupaten Malinau juga harus menerapkan sanksi yang tegas bagi masyarakat yang tidak mengurus Izin Mendirikan Bangunan (IMB), karena selama pelaksanaan penerbitan Izin Mendirikan Bangunan (IMB) oleh Camat Malinau Barat setelah diberlakukannya Peraturan Bupati Malinau Nomor 14 Tahun 2011 belum pernah dilakukan pemberian sanksi yang tegas kepada masyarakat yang mendirikan bangunan tanpa ada Izin Mendirikan Bangunan (IMB).

\section{Faktor sarana atau fasilitas}

Faktor sarana atau fasilitas sangat menentukan penegakan hukum agar berjalan sesuai dengan harapan. Sarana atau fasilitas tersebut, antara lain mencakup tenaga manusia yang berpendidikan dan terampil, organisasi yang baik, peralatan yang memadai, keuangan yang cukup, dan seterusnya. ${ }^{18}$ Sarana atau fasilitas adalah pendukung kegiatan untuk menjalankan sistem perizinan dalam hal ini adalah melaksanakan dan menjalankan penerbitan Izin Mendirikan Bangunan (IMB) oleh Camat Malinau Barat berdasarkan Peraturan Bupati Malinau Nomor 14 Tahun 2011 Tentang Pendelegasian Sebagian Wewenang Bupati Kepada Camat.

Kendala dalam melaksanakan penerbitan Izin Mendirikan Bangunan (IMB) yang dilakukan oleh Camat Malinau Barat setelah diberlakukannya Peraturan Bupati Malinau Nomor 14 Tahun 2011 adalah ketika aparatur Pemerintah Kecamatan Malinau Barat melakukan pengecekan ke lapangan sarana transportasi yang dianggap belum memadai karena terkadang ketika ingin melakukan pengecekan mobil dinas Kecamatan di pakai untuk kegiatan dinas lainnya dan apabila menggunakan kendaraan pribadi kendalanya adalah tidak ada biaya akomodasi dari Pemerintah berkaitan hal tersebut. ${ }^{19}$ Sehingga faktor sarana atau fasilitas merupakan salah satu faktor dalam melaksanakan penerbitan Izin Mendirikan Bangunan (IMB) yang dilakukan oleh Camat berdasarkan Peraturan Bupati Malinau Nomor 14 Tahun 2011 tidak berjalan secara efektif.

Untuk menegakkan penerbitan Izin Mendirikan Bangunan (IMB) oleh Camat Malinau Barat setelah diberlakukannya Peraturan Bupati Malinau Nomor 14 Tahun 2011 di Kecamatan Malinau Barat khususnya di Desa Tanjung Lapang, Desa Taras, Desa Sentaban dan Desa Long Bila, pemerintah daerah Kabupaten Malinau harus menyediakan sarana atau fasilitas kepada Pemerintah Kecamatan Malinau Barat agar dengan adanya sarana atau fasilitas yang lengkap maka pelaksanaan penerbitan Izin Mendirikan Bangunan (IMB) yang dilakukan oleh Camat Malinau Barat tersebut dapat berjalan secara efektif.

18 Soerjono Soekanto, Op.cit., hlm. 37.

19 Wawancara dengan Syahrinnudin, Kepala Seksi Ketertiban Umum Kecamatan Malinau Barat, 14 Agustus 2014. 


\section{Faktor masyarakat}

Kepatuhan masyarakat terhadap hukum merupakan satu indikator berfungsinya hukum dalam hal ini berfungsinya penerbitan Izin Mendirikan Bangunan (IMB) yang dilakukan oleh Camat Malinau Barat setelah diberlakukannya Peraturan Bupati Malinau Nomor 14 Tahun 2011 Tentang Pendelegasian Sebagian Wewenang Bupati Kepada Camat di Desa Tanjung Lapang, Desa Taras, Desa Sentaban dan Desa Long Bila Kecamatan Malinau Barat.

Camat Malinau Barat yang telah diberikan kewenangan dari Bupati Kabupaten Malinau untuk melaksanakan penerbitan Izin Mendirikan Bangunan (IMB) skala kecil berdasarkan Peraturan Bupati Malinau Nomor 14 Tahun 2011 melakukan sosialisasi kepada masyarakat di Kecamatan Malinau Barat khususnya di Desa Tanjung Lapang, Desa Taras, Desa Sentaban dan Desa Long Bila. Namun yang terjadi dilapangan bahwa setelah sosialiasi tersebut, pelaksanaan penerbitan Izin Mendirikan Bangunan (IMB) yang dilakukan oleh Camat Malinau Barat setelah diberlakukannya Peraturan Bupati Malinau Nomor 14 Tahun 2011 tidak membuat masyarakat Desa Tanjung Lapang, Desa Taras, Desa Sentaban dan Desa Long Bila mentaati hukum atau menghasilkan kepatuhan.

Ada juga masyarakat dari Desa Tanjung Lapang, Desa Taras, Desa Sentaban dan Desa Long Bila dengan sendirinya taat terhadap penerbitan Izin Mendirikan Bangunan (IMB) oleh Camat Malinau Barat setelah diberlakukanya Peraturan Bupati Nomor 14 Tahun 2011 dengan memiliki Izin Mendirikan Bangunan (IMB) dan ada masyarakat yang dengan sengaja tidak mentaati penerbitan Izin Mendirikan Bangunan (IMB) oleh Camat Malinau Barat setelah diberlakukannya Peraturan Bupati Malinau Nomor 14 Tahun 2011 karena beberapa faktor seperti takut dikenakan biaya adaministrasi yang besar, tidak mengerti proses pengajuan permohonan Izin Mendirikan Bangunan (IMB) serta bahkan ada masyarakat yang tidak mau tahu adanya Peraturan Bupati Nomor 14 Tahun 2011 karena dianggap tidak penting.

Pola pikir masyarakat ini yang menjadi salah satu faktor penegakan dan efektivitas penerbitan Izin Mendirikan Bangunan (IMB) yang dilakukan oleh Camat Malinau Barat setelah diberlakukannya Peraturan Bupati Malinau Nomor 14 Tahun 2011 menjadi terhambat, sebagai masyarakat sudah seharusnya mentaati peraturan perundangundangan yang dibuat oleh penegak hukum berkaitan dengan perizinan maka masyarakat Kecamatan Malinau Barat di Desa Tanjung Lapang, Desa Taras, Desa Sentaban dan Desa Long Bila harus mentaati Peraturan Bupati Malinau Nomor 14 Tahun 2011 dengan cara mengurus Izin Mendirikan Bangunan (IMB) di Kecamatan Malinau Barat, sehingga terciptalah tertib hukum dikalangan masyarakat Kecamatan Malinau Barat.

\section{Faktor kebudayaan}

Indonesia merupakan suatu masyarakat majemuk (plural society), terdapat banyak 
golongan etnik dengan kebudayaankebudayaan khusus. Bagian terbesar penduduk Indonesia tinggal diwilayah pedesaan yang berbeda ciri-cirinya dengan perkotaan, sehingga masalah-masalah yang timbul di wilayah pedesaan mungkin harus lebih banyak ditangani dengan cara-cara tradisional. ${ }^{20}$ Kebudayaan hukum pada dasarnya mencakup nilai-nilai yang mendasari hukum yang berlaku, nilai-nilai yang merupakan konsepsikonsepsi abstrak mengenai yang dianggap baik (sehingga dianuti) dan apa yang dianggap buruk (sehingga dihindari). ${ }^{21}$

Masyarakat Kabupaten Malinau juga memiliki golongan etnik. Suku asli Malinau antara lain yaitu Suku Dayak Tidung, Suku Dayak Kenyah, Suku Dayak Bulusu, Suku Dayak Tagol, Suku Dayak Merap, Suku Dayak Punan, Suku Dayak Abay dan Suku Dayak Lun Bawang/Lun Dayeh. ${ }^{22}$ Namun seiring dengan perkembangan pertumbuhan masyarakat, kini di Kabupaten Malinau tidak hanya terdapat suku Dayak saja, ada juga suku-suku lain seperti Suku Jawa, Suku Banjar, Suku Bugis, Suku Manado, Suku Batak dan lain sebagainya.

Seiring dengan perkembangan masyarakat tersebut, kebutuhan akan pembangunan tempat tinggal maupun tempat usaha juga terus berkembang pesat di Kabupaten Malinau, demikian pula yang terjadi di
Kecamatan Malinau Barat. Perkembangan pembangunan di wilayah Kecamatan Malinau Barat khususnya di Desa Tanjung Lapang, Desa Taras, Desa Sentaban dan Desa Long Bila juga terus berkembang pesat. Akan tetapi pembangunan tempat tinggal atau tempat usaha yang dilakukan oleh masyarakat tersebut, dibangun tanpa adanya Izin Mendirikan Bangunan (IMB). Hal tersebut dikarenakan kebiasaan-kebiasaan masyarakat Kabupaten Malinau termasuk masyarakat yang berada di Desa Tanjung Lapang, Desa Taras, Desa Sentaban dan Desa Long Bila Kecamatan Malinau Barat apabila membangun rumah tidak pernah menggunakan Izin Mendirikan Bangunan (IMB) dan menganggap bahwa Izin Mendirikan Bangunan (IMB) bukan sesuatu yang penting. ${ }^{23}$ Sehingga dengan demikian, banyak masyarakat di Desa Tanjung Lapang, Desa Taras, Desa Sentaban dan Desa Long Bila mendirikan bangunan tanpa mengurus Izin Mendirikan Bangunan (IMB) di Kecaman Malinau Barat maupun di Kantor Pelayanan Terpadu Kabupaten Malinau.

Faktor kebiasaan masyarakat yang mendirikan bangunan tanpa Izin Mendirikan Bangunan (IMB) ini yang menjadi salah satu faktor penghambat pelaksanaan penerbitan Izin Mendirikan Bangunan (IMB) oleh Camat Malinau Barat setelah diberlakukannya Peraturan Bupati Malinau Nomor 14 Tahun

20 Soerjono Soekanto, Op.cit., hlm. 50.

21 Soerjono Soekanto, Ibid., hlm. 59-60.

22 Dinas Pariwisata Kabupaten Malinau, Info Wisata Kaltara, http://infowisatakaltara.blogspot.com/2013/12/ penduduk-adat-istiadat-dan-kebudayaan-kabupaten-malinau.html?m=1, diakses 29 November 2014 pukul 09.30 WIB.

23 Wawancara dengan Marten Murang, Masyarakat Desa Sentaban Kecamatan Malinau Barat, 12 Agustus 2014. 
2011 Tentang Pendelegasian Sebagian Wewenang Bupati Kepada Camat. Sehingga kebiasaan masyarakat tersebut harus diubah dengan diberikan penjelasan dan pemahaman melalui sosialisasi dari Pemerintah Daerah Kabupaten Malinau mengenai pentingnya memiliki Izin Mendirikan Bangunan (IMB), agar pelaksanaan penerbitan Izin Mendirikan Bangunan (IMB) oleh Camat berdasarkan Peraturan Bupati Malinau Nomor 14 Tahun 2011 dapat berjalan sesuai dengan yang diharapkan oleh Pemerintah Daerah Kabupaten Malinau.

Pemerintah Daerah Kabupaten Malinau dalam hal ini ada Kantor Pelayanan Terpadu (KPT) Kabupaten Malinau dan Pemerintah Kecamatan Malinau Barat harus mengenal kebudayaan atau kebiasaan masyarakat dalam suatu wilayah termasuk masyarakatmasyarakat yang berada di Desa Tanjung Lapang, Desa Taras, Desa Sentaban dan Desa Long Bila. Dengan melakukan pengenalan terhadap kebudayaan atau kebiasaan masyarakat dalam suatu wilayah tersebut maka anggapan-anggapan masyarakat yang tadinya menganggap bahwa Izin Mendirikan Bangunan (IMB) tidak penting bisa mengalami perubahan-perubahan pandangan. Perubahanperubahan tersebut dapat dilakukan melalui penjelasan atau penyuluhan atau sosialisasi hukum yang berkesinambungan dan hasilnya dievaluasi untuk kemudian dapat dikembangkan lagi. Melalui kegiatan tersebut maka dapat menempatkan penerbitan Izin Mendirikan Bangunan (IMB) yang dilakukan oleh Camat Malinau Barat setelah diberlakukannya Peraturan Bupati Malinau Nomor 14 Tahun 2011 Tentang Pendelegasian Sebagian Wewenang Bupati Kepada Camat pada pelaksanaan yang sebenarnya dan dapat berjalan secara efektif.

\section{Simpulan}

1. Tingkat efektivitas penerbitan Izin Mendirikan Bangunan (IMB) yang dilakukan oleh Camat Malinau Barat setelah diberlakukannya Peraturan Bupati Malinau Nomor 14 Tahun 2011 belum berjalan secara efektif karena dari segi faktor struktur; Kantor Pelayanan Terpadu (KPT) dan Pemerintah Kecamatan Malinau Barat hanya melakukan sosialisasi, Pemerintah Kecamatan Malinau Barat juga belum memahami dengan benar isi dari Peraturan Bupati Malinau Nomor 14 Tahun 2011 karena menerbitkan Izin Mendirikan Bangunan (IMB) skala besar serta dengan perhitungan biaya retribusi yang tidak sesuai dalam Peraturan Bupati Malinau Nomor 14 Tahun 2011. Substansi; Peraturan Bupati Malinau Nomor 14 Tahun 2011 belum jelas karena tidak mencantumkan mengenai ukuran yang tepat dan terperinci Izin Mendirikan Bangunan (IMB) skala kecil. Kultur; Sikap masyarakat yang tidak mau mematuhi Peraturan Bupati Malinau Nomor 14 Tahun 2011 disebabkan beberapa (a) tidak mengerti proses 
pembuatan Izin Mendirikan Bangunan (IMB), (b) takut dikenakan biaya retribusi yang besar, (c) menganggap Izin Mendirikan Bangunan (IMB) tidak penting.

2. Faktor atau unsur dominan yang paling berpengaruh terhadap tingkat efektivitas penerbitan Izin Mendirikan Bangunan (IMB) oleh Camat Malinau Barat setelah diberlakukannya Peraturan Bupati Malinau Nomor 14 Tahun 2011 yaitu Faktor Hukum; Adanya ketidakjelasan mengenai ukuran Izin Mendirikan Bangunan (IMB) skala kecil. Faktor Penegak Hukum; Dinas Tata Kota Kabupaten Malinau dan Satuan Polisi Pamong Praja tidak pernah dilibatkan dalam pengawasan dan penertiban kepada masyarakat yang tidak memiliki Izin Mendirikan Bangunan (IMB). Faktor Sarana atau Fasilitas; Sarana transportasi bagi Pemerintah Kecamatan Malinau Barat belum memadai. Faktor Masyarakat; Adanya masyarakat yang tidak mengetahui bahkan dengan segaja tidak mengindahkan Peraturan Bupati Malinau Nomor 14 Tahun 2011. Faktor Kebudayaan; Adanya kebiasaan masyarakat yang membangun rumah tanpa adanya Izin Mendirikan Bangunan (IMB) dan menganggap bahwa Izin Mendirikan Bangunan (IMB) bukan sesuatu yang dianggap penting.

\section{DAFTAR PUSTAKA}

\section{Buku}

Achmad Ali, 2009, Menguak Teori Hukum

(Legal Theory) dan Teori Peradilan (Judicialprudence) termasuk

Interpretasi Undang-undang

(Legisprudence), Prenada Media Group, Jakarta.

Agussalim Andi Gadjong, 2007,

Pemerintahan Daerah Kajian Politik

dan Hukum, Ghalia Indonesia, Bogor.

Diana Halim Koentjoro, 2004, Hukum

Administrasi Negara, Ghalia Indah, Bogor Selatan.

Makmur, 2011, Efektivitas Kebijakan

Kelembagaan Pengawasan, Refika Aditama Bandung.
Ridwan HR, 2010, Hukum Administrasi

Negara, RajaGrafindo Persada Jakarta.

Soerjono Soekanto, 1996, Pengantar Penelitian Hukum, Cetak ke-III, UI-Press, Jakarta. 2010, Faktor-faktor yang Mempengaruhi Penegakan Hukum, RajaGrafindo Persada, Jakarta.

Y. Sri Pudyatmoko, 2009, Perizinan Problem dan Upaya Pembenahan, Gramedia Widiasarana Indonesia, Jakarta.

\section{Peraturan Perundang-undangan}

Peraturan Daerah Kabupaten Malinau Nomor 5 Tahun 2001 tentang Izin Mendirikan Bangunan. 
Peraturan Bupati Malinau Nomor 14 Tahun 2011 tentang Pendelegasian Sebagian Wewenang Bupati Kepada Camat.

\section{Naskah Internet}

Dinas Pariwisata Kabupaten Malinau, Info Wisata Kaltara, http:// infowis atakaltara.blogspot. com/2013/12/penduduk-adat-istiadatdan-kebudayaan-kabupaten-malinau. $\mathrm{html}$ ? $\mathrm{m}=1$. 